\title{
Oculopalatal tremor and severe late-onset cerebellar ataxia
}

\section{Figure 1 Radiologic findings}

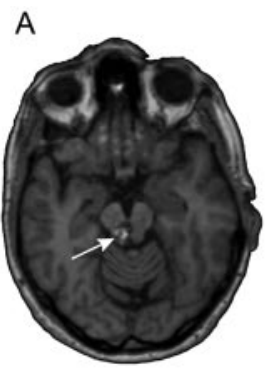

B

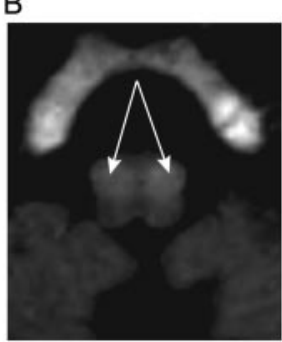

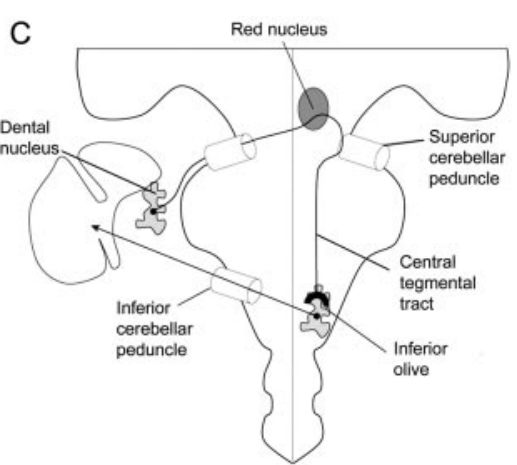

(A) Axial T1-weighted MRI (1.5 T) shows the cavernoma (arrow) localized at right sided paramedian mesencephalic level. (B) Axial T2-weighted MRI shows bilateral inferior olive hyperintensity (arrows) at caudal medullar level. (C) Schema of the Guillain-Mollaret triangle.

\section{Figure 2 Diffusion tensor MRI results}
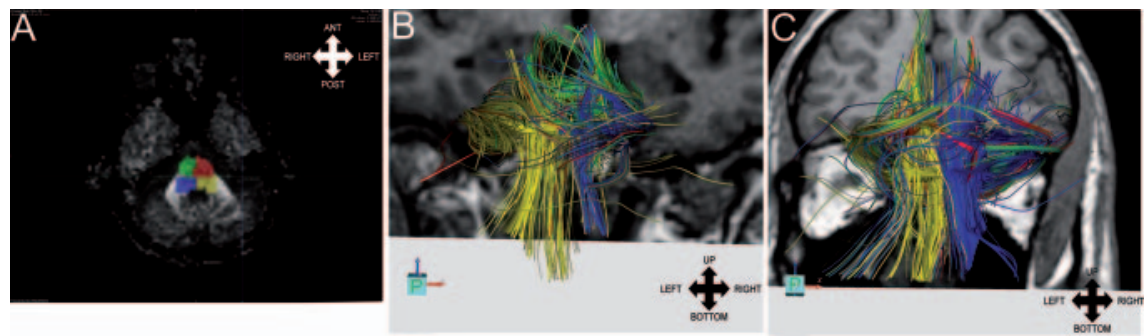

(A) Four regions of interest were positioned at pontine level, delimitating right and left parts of tegmentum and basal pons. $(\mathrm{B}, \mathrm{C})$ Dorsal view of the fiber tracts superimposed on coronal T1weighted MRI shows decreased fiber density of right pontine tegmentum tract (blue) in the patient (B) as compared to the control (C).

Following four recurrent bleedings of a mesencephalic cavernoma within 10 years (figure 1A), a 62-year-old woman demonstrated left kinetic cerebellar syndrome. She then developed oculopalatal tremor (OPT) associated with bilateral inferior olive hyperintensity (figure 1B). Gamma knife radiation was performed, but she developed severe cerebellar ataxia. OPT secondary to brainstem strokes and associated with progressive ataxia is rare. ${ }^{1}$ Diffusion tensor MRI (DTI) showed decreased number of fibers in the right tegmentum of the patient as compared to a control subject (figure 2). These results give credit to the hypothesis of central tegmental tract interruption in pathophysiology of OPT (figure 1C). ${ }^{2}$

Caroline Tilikete, MD, PhD; Salem Hannoun, MS; Norbert Nighoghossian, MD, PhD; and Dominique Sappey-Marinier, PhD, Bron Cedex, France

Disclosure: The authors report no disclosures.

Address correspondence and reprint requests to Dr. Caroline Tilikete, UMR-S864, Espace et Action, 16 avenue du doyen Lépine, 69676 BRON Cedex, France; caroline.tilikete@inserm.fr

1. Eggenberger E, Cornblath W, Stewart DH. Oculopalatal tremor with tardive ataxia. J Neuro-ophthalmol 2001;21:83-86.

2. Guillain G, Mollaret P. Deux cas de myoclonies synchrones et rythmées vélo-pharyngo-oculo-diaphragmatiques. Le problème anatomique et physio-pathologique de ce syndrome. Rev Neurol 1931;2:545-566. 


\title{
Neurology
}

\author{
Oculopalatal tremor and severe late-onset cerebellar ataxia \\ Caroline Tilikete, Salem Hannoun, Norbert Nighoghossian, et al. \\ Neurology 2008;71;301 \\ DOI 10.1212/01.wnl.0000318287.29513.6d
}

This information is current as of July 21, 2008

\section{Updated Information \& Services}

References

Citations

Subspecialty Collections

Permissions \& Licensing

Reprints including high resolution figures, can be found at: http://n.neurology.org/content/71/4/301.full

This article cites 2 articles, 0 of which you can access for free at: http://n.neurology.org/content/71/4/301.full\#ref-list-1

This article has been cited by 1 HighWire-hosted articles: http://n.neurology.org/content/71/4/301.full\#\#otherarticles

This article, along with others on similar topics, appears in the following collection(s):

Intracerebral hemorrhage

http://n.neurology.org/cgi/collection/intracerebral_hemorrhage

MRI

http://n.neurology.org/cgi/collection/mri

Nystagmus

http://n.neurology.org/cgi/collection/nystagmus

Ocular motility

http://n.neurology.org/cgi/collection/ocular_motility

Tremor

http://n.neurology.org/cgi/collection/tremor

Information about reproducing this article in parts (figures,tables) or in its entirety can be found online at:

http://www.neurology.org/about/about_the_journal\#permissions

Information about ordering reprints can be found online:

http://n.neurology.org/subscribers/advertise

Neurology ${ }^{\circledR}$ is the official journal of the American Academy of Neurology. Published continuously since 1951, it is now a weekly with 48 issues per year. Copyright . All rights reserved. Print ISSN: 0028-3878. Online ISSN: 1526-632X.

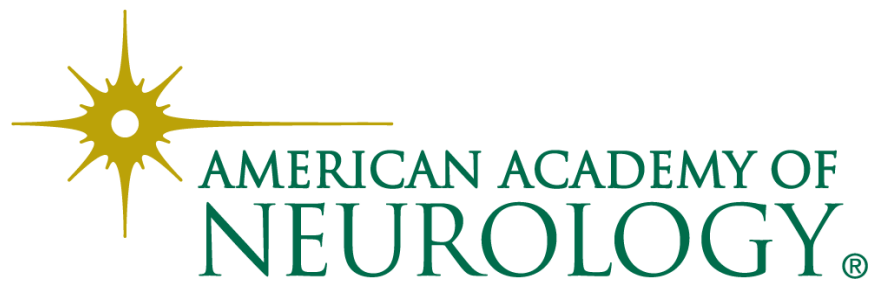

